\title{
KARAKTERISASI TERMOKOPEL TIPE K PADA FASILITAS SIMULASI SISTEM FASSIP-02
}

\author{
Sumantri Hatmoko, Kussigit Santosa, Giarno, Dedy Haryanto, Mulya Juarsa, \\ M. Hadi Kusuma, Anhar Riza Antariksawan dan Surip Widodo \\ Pusat Teknologi dan Keselamatan Reaktor Nuklir, Badan Tenaga Nuklir Nasional \\ e-mail: sumantri_08@batan.go.id
}

\begin{abstract}
In the activities of the Pratama Insinas, Ministry of Higher Education technology research in 2018, PTKRN BATAN built a testing facility that simulates a passive cooling system on the reactor core when there is a loss of outside power. The test facility is the Passive-02 System Simulation Facility (FASSIP02). In FASSIP-02 there are several parameters that need to be measured, one of which is temperature. In the measurement of temperature using a K type Thermocouple connected to the National Instrument 9178 and 9213 modules that use computer programming with LabVIEW software. Temperature measurements need to be characterized. Characterization of type K thermocouples was carried out using thermobaths, 30 type K thermocouples, standard thermocouples, National Instrument modules 9178 and 9213 with computer programming displays using LabVIEW software. The method used for characterization of type $K$ thermocouples is a fixed temperature comparison method where the results of the temperature control of thermobath is 30-90 C compared with the results of measurements from the type $K$ thermocouple and standard thermocouple. From the difference of the copper-wrapped junction tip thermocouple without the copper-wrapped and standard thermocouple produces a small error value, so the use of copper as a thermocouple junction end wrapper can be used as a temperature measurement FASSIP-02.
\end{abstract}

Keywords: Characterization, Thermocouple type K, FASSIP-02.

\section{PENDAHULUAN}

Kecelakaan Pembangkit Listrik Tenaga Nuklir (PLTN) karena kehilangan pendingin dari teras reaktor pernah terjadi di reaktor Fukushima Jepang. Kecelakaan reaktor tersebut terjadi pada tanggal 11 Maret 2011, pukul 14.46 diikuti dengan gempa bumi yang menimbulkan tsunami. Seluruh reaktor fukushima shutdown secara otomatis. Emergency Diesel Generator (EDC) untuk sistem pendingin reaktor beroperasi dengan sukses. Karena banjir dan kerusakan jaringan listrik mengakibatkan catu daya mati total (Station blackout) sehingga Emergency Diesel Generator (EDC) untuk sistem pendingin reaktor gagal berfungsi.

Kegagalan sistem pendingin reaktor dalam jangka panjang mengakibatkan suhu di teras dan perangkat bahan bakar meningkat dengan cepat. Kenaikan suhu pada bahan bakar mengakibatkan kelongsong bahan bakar meleleh dan pecah serta tekanan di dalam pengungkung reaktor mencapai 8 bar akibat produksi gas hidrogen makin meningkat [1]. Untuk menghindari ledakan di teras reaktor, teras reaktor didinginkan dengan air, kemudian tekanan di dalam pengungkung harus dikurangi dengan melepaskan gas hidrogen ke luar [2]. Hal ini mengakibatkan ledakan dahsyat di luar pengungkung disertai lepasnya hasil produk fisi ke lingkungan. Oleh sebab itu maka pengembangan dan penelitian keselamatan sistem pasif perlu dilakukan. Keselamatan sistem pasif adalah sistem yang bekerja dengan prinsip sirkulasi alamiah (natural circulation) memanfaatkan perbedaan kerapatan fluida dan gravitasi [3]. Dalam rangka kegiatan insinas kemenristekdikti tahun 2018 PTKRN BATAN membangun fasilitas uji yang mesimulasikan keselamatan sistem pasif yang bekerja dengan pronsip sirkulasi alamiah. Fasilitas tersebut adalah Fasilitas Simulasi Sistem Pasif (FASSIP-02). Di dalam FASSIP-02 terdapat beberapa parameter yang diukur yaitu temperatur, tekanan dan laju alir [4]. Dalam pengukuran temperatur menggunakan Termokopel tipe K terkoneksi dengan modul National Instrument 9178 dan 9213 dengan tampilan pemograman komputer menggunakan software LabVIEW. Beberapa peneliti telah melakukan penelitian tentang karakteristik termokopel yaitu Achmad Suntoro telah melakukan Karakteristik Termokopel Tungsten-Rhenium [5]. Karakteristik Perbandingan Termokopel Tipe K, Termokopel Tipe E, Termokopel Tipe K, Dan Termokopel Tipe N. Untuk suhu $0^{\circ} \mathrm{C}$ sampai suhu $100^{\circ} \mathrm{C}$ telah dilakukan oleh Putra Dwi Ramada [6]. Berdasarkan uraian di atas maka penelitian karakterisasi termokopel $\mathrm{K}$ pada FASSIP-02 dapat dilakukan. Karakterisasi termokopel tipe $\mathrm{K}$ dilakukan dengan menggunakan thermobath, termokopel tipe $\mathrm{K}$ 
sebanyak 30 buah, termokopel standar, modul National Instrument (NI) 9178 dan 9213 dengan tampilan pemograman komputer menggunakan software LabVIEW. Metode yang digunakan untuk karakterisasi termokopel tipe $\mathrm{K}$ adalah dengan metode perbandingan suhu tetap dimana hasil dari kontrol temperatur dari thermobath yaitu $30-90^{\circ} \mathrm{C}$ dibandingkan dengan hasil pengukuran dari termokopel tipe $\mathrm{K}$ dan termokopel standar. Tujuan dari karakterisasi ini adalah agar hasil dari pengukuran dengan alat ukur yang telah dikarakterisasi dapat diandalkan keberhasilannya. Hasil dari karakterisasi ini adalah hasil uji dari termokopel tipe $\mathrm{K}$ yang akan digunakan untuk pengukuran temperatur untuk FASSIP-02.

\section{DESKRIPSI SISTEM FASSIP-02}

FASSIP-02 adalah fasilitas eksperimen yang terdapat pada PTKRN BATAN digunakan untuk mensimulasikan fenomena aliran sirkulasi alamiah pada pengembangan sistem keselamatan PLTN baik pada kondisi kecelakaan maupun pada kondisi operasi [7]. Dalam rangka kegiatan Insinas Kemenristekdikti tahun 2018 di labolatorium PTKRN BATAN di bangun Fasilitas Simulasi Sistem Pasif (FASSIP-02). FASSIP-02 terdiri dari beberapa bagian utama yaitu Water Heater Tank (WHT), Pemipaan, Expantion Tank dan Water Cooling Tank (WCT). Gambar FASSIP-02 dapat dilihat pada Gambar 1.

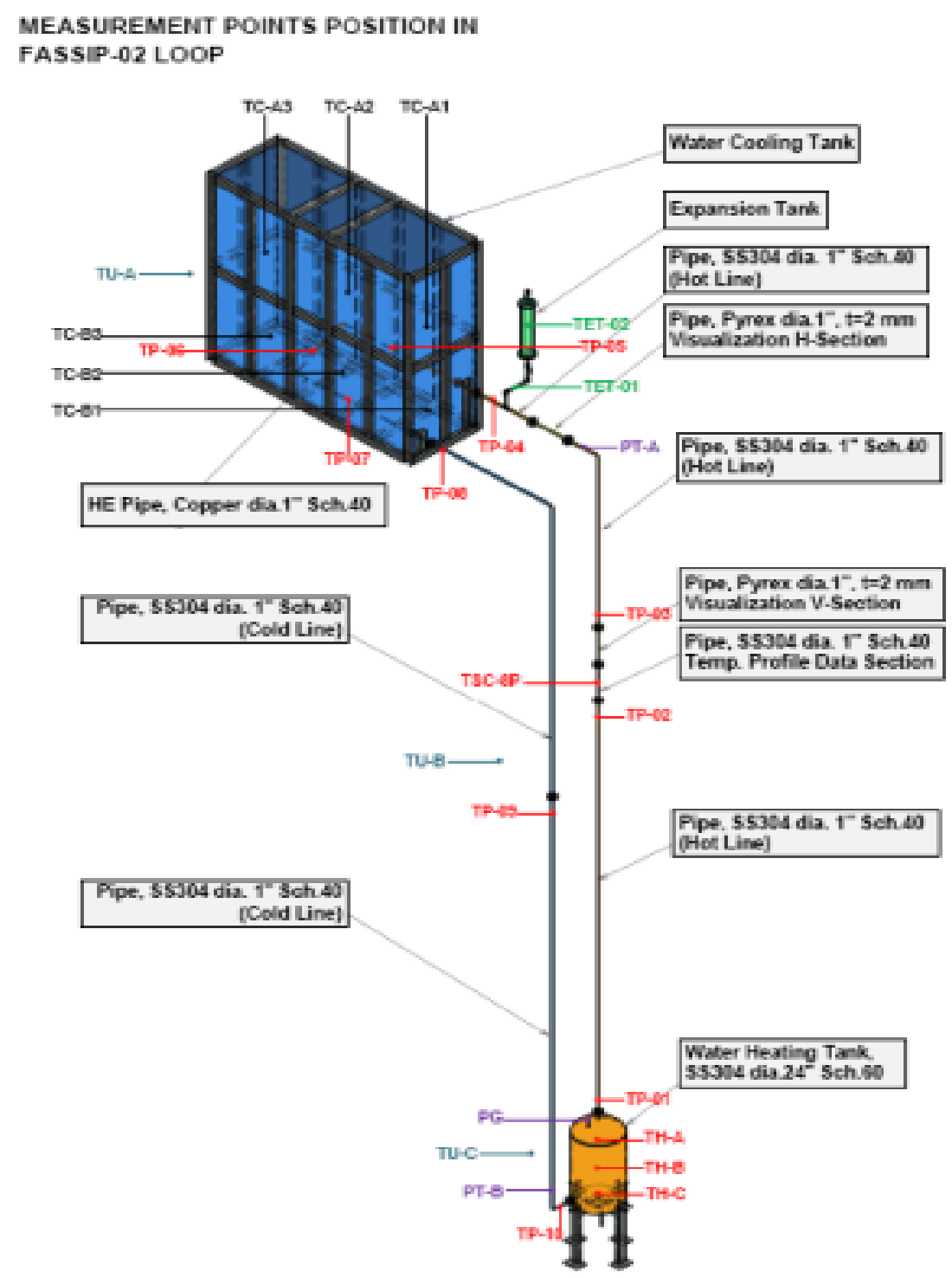

Gambar 1. FASSIP-02 (Dokumen teknis FASSIP-02) 
Di dalam sistem FASSIP-02 ada beberapa parameter yang diukur yaitu temperatur, tekanan dan laju alir. Untuk pengukuran temperatur pada sistem FASSIP-02 menggunakan Termokopel tipe K terkoneksi dengan modul National Instrument 9178 dan 9213 dengan tampilan pemograman komputer menggunakan software LabVIEW.

Termokopel adalah sepasang kawat logam jenis yang tidak sama jenisnya dihubungkan bersama-sama yang apabila kedua ujungnya masing-masing dimasukan ke dalam dua tempat yang berbeda suhunya, maka timbul gaya gerak listrik temperatur antara kedua ujungnya [8]. Termokopel tipe $\mathrm{K}$ memiliki rentang pengukuran dari $-200^{\circ} \mathrm{C}$ sampai dengan $1250^{\circ} \mathrm{C}$ dan menggunakan logam nickel-cromium dan nickel-alumunium pada kedua ujung logamnya [9].

Karakteristik alat ukur adalah pekerjaan menyeluruh (persiapan, pelaksanaan dan analisis) dapat diandalkan keberhasilannya. Salah satu karakteristik penting dari alat ukur tersebut adalah ketelitian atau accuracy. Ketelitian didefenisikan sebagai ukuran seberapa jauh hasil pengukuran mendekati harga sebenarnya [10]. Ukuran ketelitian sering dinyatakan dengan dua cara, atas dasar perbedaan atau kesalahan (error) terhadap harga yang sebenarnya, yaitu:

a. Kesalahan harga sebenarnya dalam proses:

$$
\text { eh }=\frac{\text { harga terukur }- \text { harga sebenarnya }}{\text { harga sebenarnya }} \times 100 \%
$$

b. Kesalahan dalam persen terhadap skala penuh:

$$
\text { eh }=\frac{\text { harga terukur }- \text { harga sebenarnya }}{\text { skala maksimum sebenarnya }} \times 100 \%
$$

\section{METODOLOGI}

Pada FASSIP-02 terdapat 30 titik pengukuran temperatur, 2 titik pengukuran tekanan dan 1 titik pengukuran laju alir. Titik pengukuran terletak pada pemipaan, WCT dan WHT pada FASSIP02. Untuk pengukuran temperatur pada FASSIP-02 menggunakan termokopel tipe K. Termokopel tipe K yang digunakan untuk pengukuran temperatur pada ujung junction terbungkus dengan pipa tembaga yang dapat ditunjukkan pada Gambar 2.

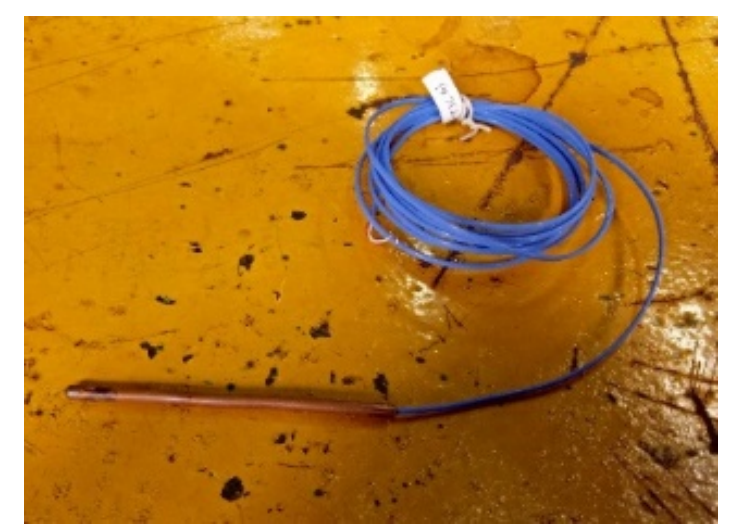

Gambar 2. Termokopel tipe K

Untuk mengelas ujung kawat termokopel menggunakan welding termokopel omega model TL-Weld. Model welding termokopel ini di desain untuk memproduksi secara komersial ujung termokopel agar dapat digunakan untuk pengukuran. Gambar welding termokopel omega model TLWeld dapat ditunjukan pada Gambar 3. 


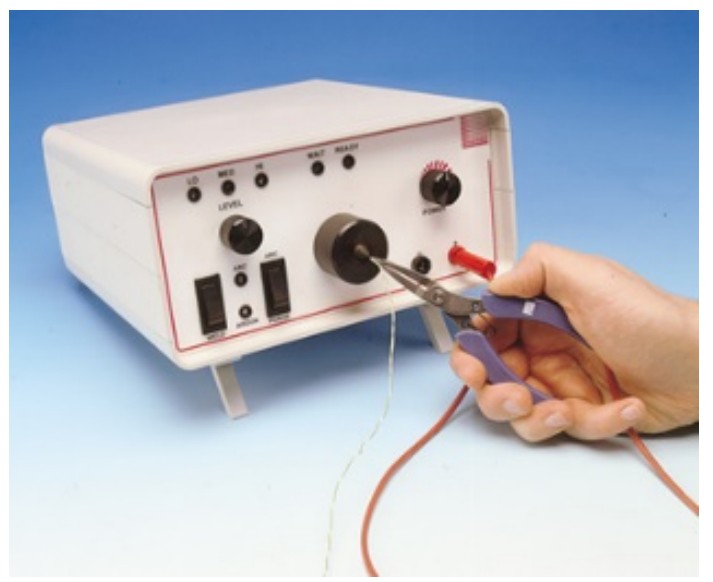

Gambar 3. Model welding termokopel TL-Weld Omega [11]

Sistem Instrumentasi yang digunakan untuk karakterisasi termokopel tipe K menggunakan modul National Instrument (NI) 9178 dan 9213. Modul chassis NI 9178 adalah modul buatan National Instrument berbasis ethernet dengan kecepatan 200.000 data/detik. Modul chassis NI 9178 menyediakan 8 slot modul National Instrument [10]. Gambar modul NI chassis 9178 dapat ditunjukkan pada Gambar 4.

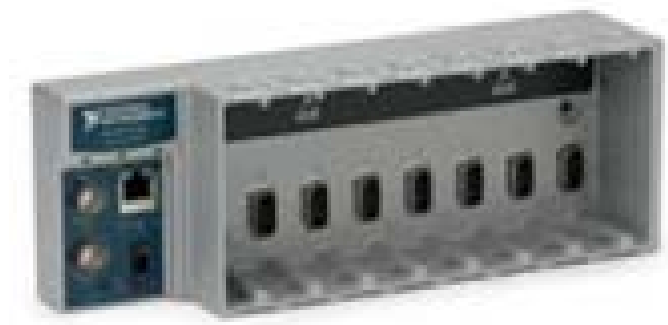

Gambar 4. Modul chassis NI 9178 [12]

Modul NI 9213 adalah modul input termokopel yang di masukkan ke modul chassis NI 9178 yang dapat mengukur temperatur dengan berbagai jenis termokopel diantaranya termokopel tipe J, K, T, E, B, R dan S. Pada ujung kabel terdapat terminal TC+ yang dihubungkan ke terminal positif termokopel dan terminal TC- yang dihubungkan ke terminal negatif termokopel. Modul tersebut mempunyai input sebanyak 16 kanal seperti tang ditunjukkan pada Gambar 5.

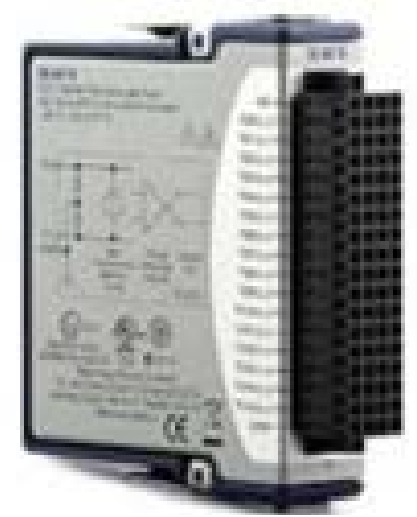

Gambar 5. Modul NI 9213 [13]

Untuk pemograman pengukuran karakterisasi termokopel tipe $\mathrm{K}$ menggunakan software LabVIEW (Laboratory Virtual Instrumentation Engineering Workbrench). LabVIEW merupakan perangkat lunak yang menggunakan bahasa pemograman grafis dengan layout visual atau 
menggunakan model aliran data. LabVIEW memiliki 2 jendela kerja yaitu block diagram dan front panel. Pada front panel menyediakan interface untuk pengguna yang akan menampilkan simulasi panel untuk instrument seperti knob, tombol dan saklar. Untuk pemograman pada LabVIEW menggunakan block diagram. Block diagram tersebut berisi perintah yang akan dijalankan pada front panel pada LabVIEW. Untuk front panel dan block diagram pada LabVIEW dapat di tunjukkan pada Gambar 6.

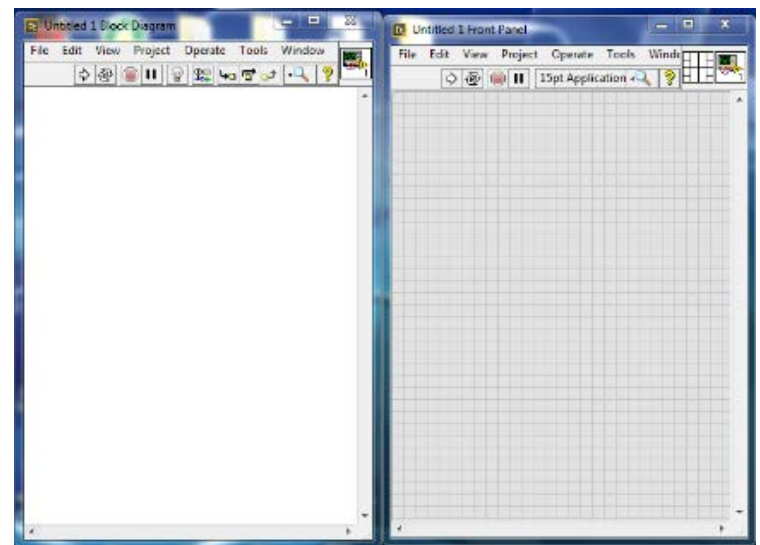

Gambar 6. Tampilan block diagram dan front panel pada LabVIEW [14]

Untuk menguji karakterisasi pengukuran temperatur dengan termokopel tipe K menggunakan alat thermobath. Thermobath bekerja dengan mengatur temperatur pada wadah pada media oli atau air untuk menghantarkan panas pada termokopel. Thermobath yang digunakan di Labolatorium PTKRN BATAN adalah thermobath RB-12A. Thermobath ini dapat menampung air sebanyak 12 liter dan telah mengalami perkembangan yaitu mengalami perubahan pada alat kontrolnya, didesain dapat mengkarakterisasi 15 termokopel dan 1 termokopel standar. Pengukuran karakterisasi termokopel telah terhubung dengan modul chassis NI 9188, 9213 dan komputer. Hasil pengukuran karakterisasi dapat ditampilkan melalui komputer dengan interface pemograman LabVIEW. Gambar thermobath dapat di sajikan pada Gambar 7.

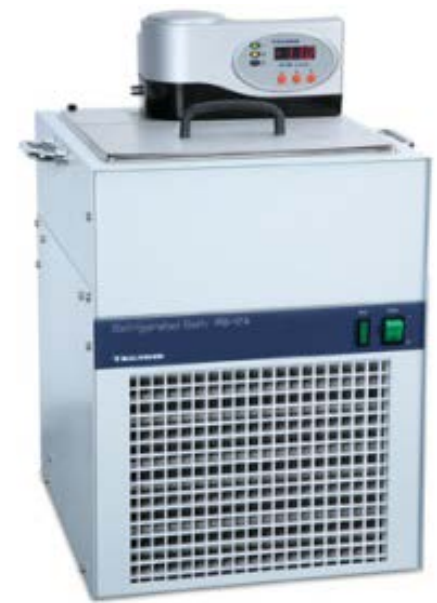

Gambar 7. Thermobath RB-12 A [15]

Tahapan pembuatan dan karakterisasi termokopel tipe K pada simulasi sistem FASSIP 02 terdiri dari beberapa tahapan sebagai berikut.

1. Membuat termokopel yang akan digunakan pada FASSIP-02.

2. Merakit sistem intrumentasi untuk pengukuran karakterisasi termokopel tipe $\mathrm{K}$

3. Membuat pemograman pengukuran karakterisasi pada termokopel tipe K. 
4. Memasukkan termokopel yang telah dibuat, termokopel standar ke thermobath yang telah berisi air

5. Jalankan pemograman pengukuran karakterisasi pada termokopel tipe $\mathrm{K}$ dan lakukan save pada pemograman LabVIEW ketika pada kontrol thermobath menujukkan pada suhu 30, 40, 50, 60, 70, 80 dan $90^{\circ} \mathrm{C}$.

6. Membuat grafik hasil karakterisasi pada termokopel tipe $\mathrm{K}$ yang terbungkus tembaga dan yang tidak terbungkus tembaga.

\section{HASIL DAN PEMBAHASAN}

1. Membuat termokopel yang akan digunakan pada FASSIP-02

Pembuatan termokopel dilakukan dengan mengelas ujung-ujung kawat termokopel dengan welding termokopel TL-Weld Omega sampai kedua ujung kawatnya tersambung (junction). Junction diberi thermal grass dan di bungkus dengan tembaga. Panjang dari termokopel tersebut disesuaikan dengan letak posisi termokopel yang akan dipasang pada FASSIP 02 dan penamaan kode pada termokopel telah di sepakati. Untuk kode termokopel pada pipa diberi kode TP, termokopel pada tangka WHT ditandai dengan TH, Pada Tangki WCT diberi kode TC, Pada pipa instrumentasi diberi kode TSC, Pada tangki Ekspansi di beri kode TET dan untuk Udara TU. Jumlah termokopel yang diuji sebanyak 30 Buah terdiri dari TP 11 buah, TH 3 buah, TC 3 buah, TSC 8 buah, TET 2 buah dan TU 3 Buah.

2. Merakit sistem instrumentasi untuk pengukuran karakterisasi termokopel tipe $\mathrm{K}$

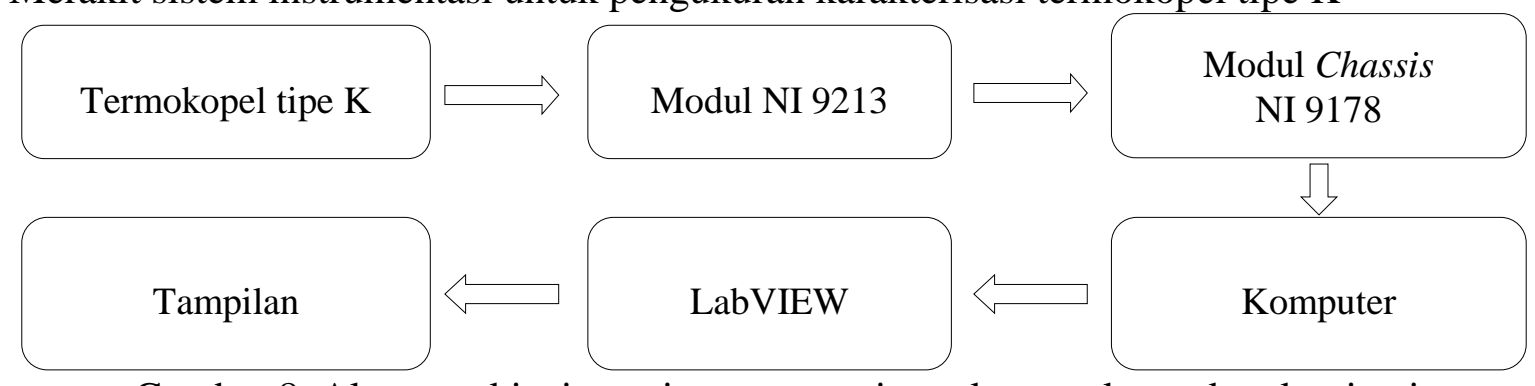

Gambar 8. Alur merakit sistem instrumentasi untuk pengukuran karakterisasi termokopel tipe K.

Pada termokopel tipe K yang telah dibuat dikoneksikan dengan modul NI 9213 beserta dengan termokopel standar. Pada modul NI 9213 terdiri dari 16 kanal termokopel. 15 kanal terkoneksi dengan termokopel yang dibuat dan 1 termokopel standar. Pada modul NI 9213 terkoneksi dengan modul chassis NI 9178. Modul chasis NI 9178 terkoneksi dengan komputer. Pada komputer terdapat program LabVIEW untuk membuat tampilan pengukuran karakterisasi termokopel tipe K.

3. Membuat pemograman pengukuran karakterisasi pada termokopel $\mathrm{K}$

Dalam pembuatan pemograman pengukuran dengan LabVIEW hal yang pertama kali dilakukan adalah dengan membuat diagram alir. Diagram alir pemograman karakterisasi termokopel tipe K dapat ditunjukkan pada Gambar 9.

Dari diagram alir tesebut, dapat dibuat program block diagram karakterisasi tipe $\mathrm{K}$ pada FASSIP-02 dengan software LabVIEW yang dapat ditunjukkan pada Gambar 10. 


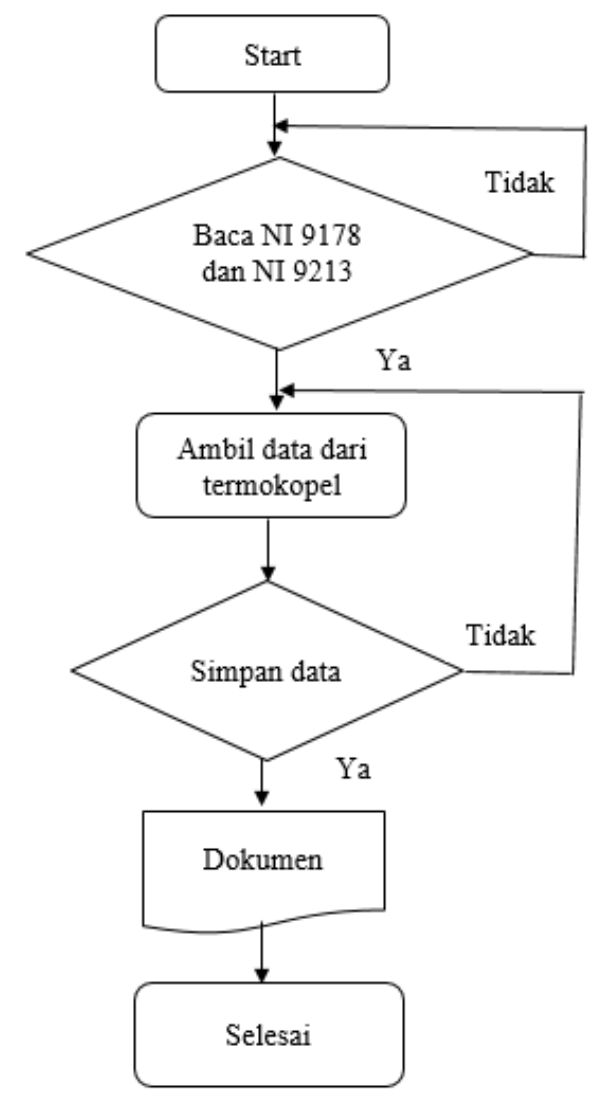

Gambar 9. Diagram alir program karakterisasi termokopel tipe K pada FASSIP-02

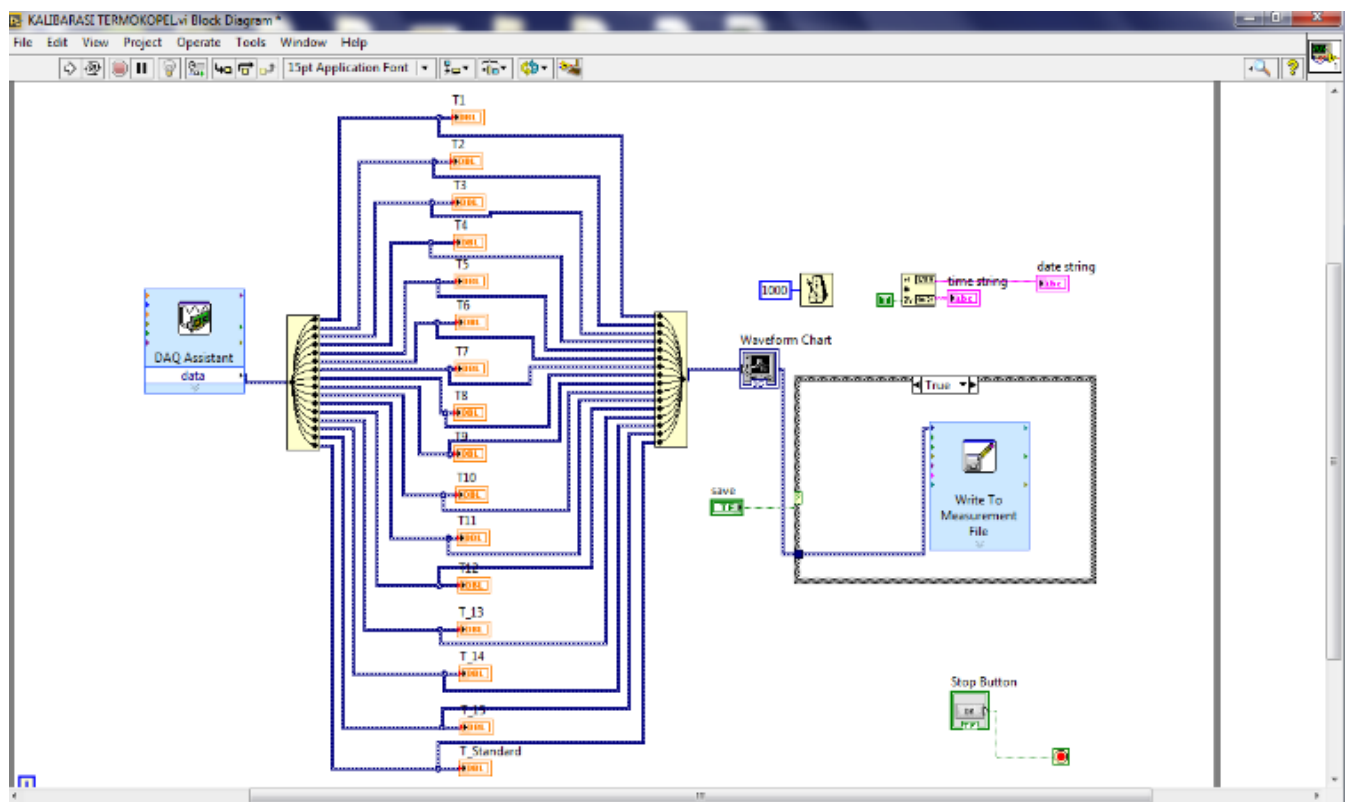

Gambar 10. Block diagram program karakterisasi termokopel tipe K pada FASSIP-02

Dari blok diagram di atas maka pada front panel pada pemograman LabVIEW akan terbentuk pada Gambar 11. 


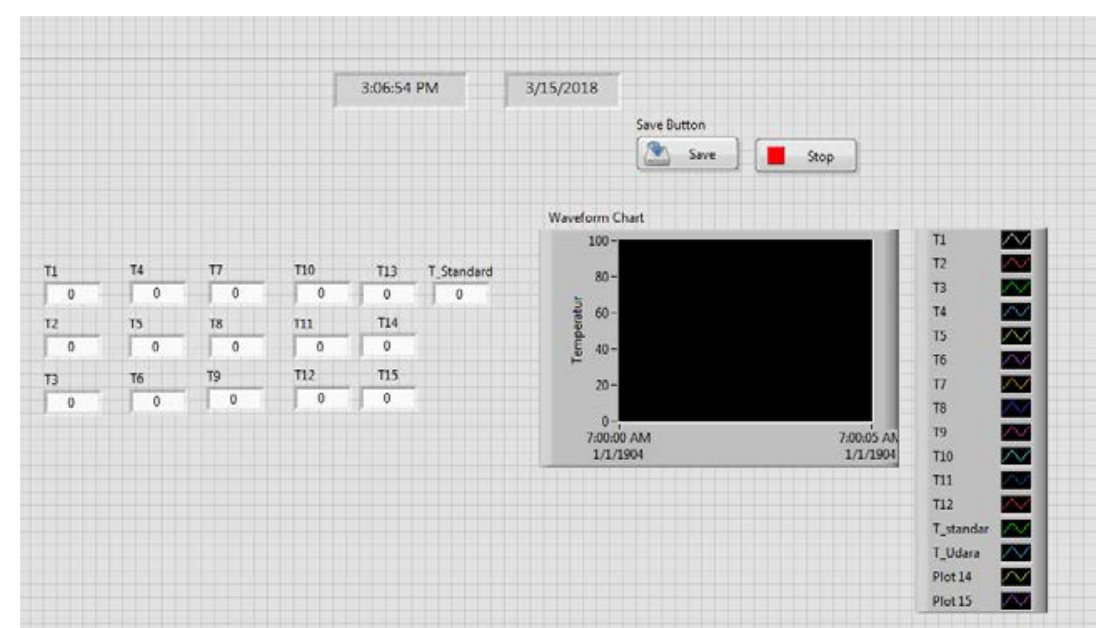

Gambar 11. Front panel program karakterisasi termokopel tipe K pada FASSIP-02

Dari tampilan front panel karakterisasi termokopel tipe K terdiri dari 16 tampilan pengukuran termokopel (15 tampilan pengukuran termokopel yang diuji dan 1 slot termokopel standar). Dari pengukuran tersebut dapat diperoleh data pengukuran yang dapat disimpan ke harddisk komputer

4. Memasukan termokopel yang telah dibuat, termokopel standar ke thermobath yang telah berisi air.

Termokopel yang akan diuji menggunakan metode perbandingan suhu tetap yaitu membandingkan nilai pengukuran termokopel dengan termokopel standard dan suhu tetap pada kontrol thermobath. Termokopel di masukan kedalam thermobath yang telah berisi air. Terdapat 16 buah termokopel yang dimasukan kedalam thermobath terdiri dari 15 buah termokopel yang akan diuji dan 1 buah termokopel standar. Termokopel yang akan diuji adaha termokopel yang terbungkus tembaga pada ujung junction dan yang tidak terbungkus tembaga. Gambar pengujian termokopel dengan thermobath dapat ditunjukkan pada Gambar 12.

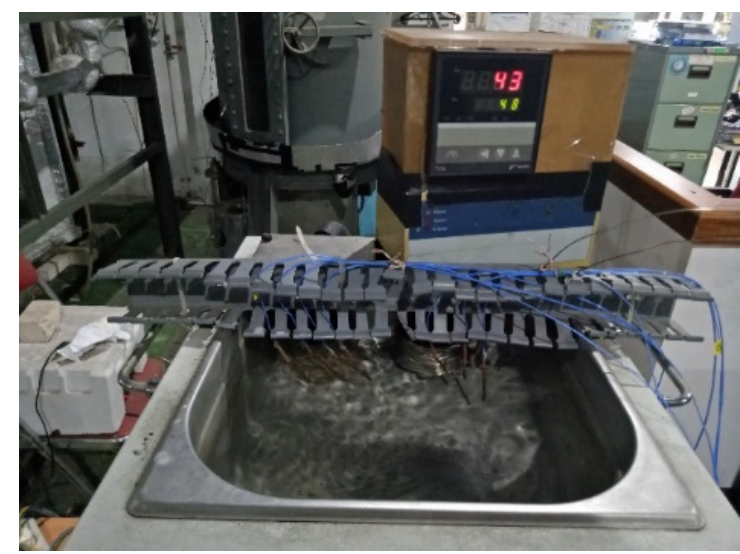

Gambar 12. Pengujian termokopel dengan thermobath

5. Jalankan pemograman pengukuran karakterisasi pada termokopel tipe $\mathrm{K}$ dan lakukan save pada pemograman LabVIEW ketika pada kontrol thermobath menujukkan pada suhu 30, 40, 50, 60, 70, 80 dan $90^{\circ} \mathrm{C}$.

Program dijalankan pada saat melakukan pengujian pada termokopel yang akan diuji, ketika temperatur pada kontrol thermobath stabil mencapai $30^{\circ} \mathrm{C}$ jalankan perintah save pada front panel pemograman untuk mengambil data pengujian. Setelah data pengujian selesai diambil tekan tombol stop pada front panel pemograman. Untuk selanjutnya lakukan hal yang sama ketika pada kontrol 
temperatur pada thermobath menunjukan temperatur stabil 40, 50, 60, 70, 80 dan $90^{\circ} \mathrm{C}$. Dari hasil pengujian maka didapat rata-rata kesalahan hasil pengujian termokopel terbungkus dengan tembaga pada junction dan tidak terbungkus dengan tembaga. Nilai kesalahan pada termokopel didapatkan dari rumus eh $=\frac{\text { harga terukur - harga sebenarnya }}{\text { harga sebenarnya }} \times 100 \%$. Dimana harga terukur adalah harga pengukuran dari termokopel tanpa tembaga (Ttt), termokopel dengan tembaga (Tdt) dan termokopel standar (Ts). Harga sebenarnya adalah harga dari set point (SP) kontrol thermobath. Hasil pengujian termokopel dapat disajikan pada Tabel 1.

Tabel 1. Hasil pengujian termokopel tipe K terbungkus tembaga dan yang tidak terbungkus tembaga dengan thermobath

\begin{tabular}{ccccccc}
\hline $\begin{array}{c}\text { Set } \\
\text { Point }\end{array}$ & $\begin{array}{c}\text { Rata-rata } \\
\text { Pengukuran Ttt }\end{array}$ & Kesalahan & $\begin{array}{c}\text { Rata-rata } \\
\text { Pengukuran Tdt }\end{array}$ & Kesalahan & Ts & Kesalahan \\
\hline 30 & 29,76 & $0,81 \%$ & 29,47 & $1,77 \%$ & 29,67 & $1,11 \%$ \\
40 & 39,46 & $1,35 \%$ & 39,20 & $1,99 \%$ & 39,58 & $1,06 \%$ \\
50 & 49,40 & $1,20 \%$ & 49,02 & $1,96 \%$ & 49,72 & $0,56 \%$ \\
60 & 58,78 & $2,03 \%$ & 58,23 & $2,95 \%$ & 58,86 & $1,91 \%$ \\
70 & 68,94 & $1,52 \%$ & 68,42 & $2,25 \%$ & 69,04 & $1,37 \%$ \\
80 & 78,56 & $1,80 \%$ & 78,21 & $2,24 \%$ & 79,55 & $0,56 \%$ \\
90 & 88,41 & $1,76 \%$ & 88,15 & $2,05 \%$ & 89,55 & $0,50 \%$ \\
\hline Rata-rata & & $1,50 \%$ & & $2,17 \%$ & & $1,01 \%$ \\
Kesalahan & & & & & & \\
\hline
\end{tabular}

6. Membuat grafik data hasil karakterisasi pada termokopel tipe $\mathrm{K}$

Dari data hasil pengujian pada tabel 1 maka dapat disajikan grafik pada Gambar 14.

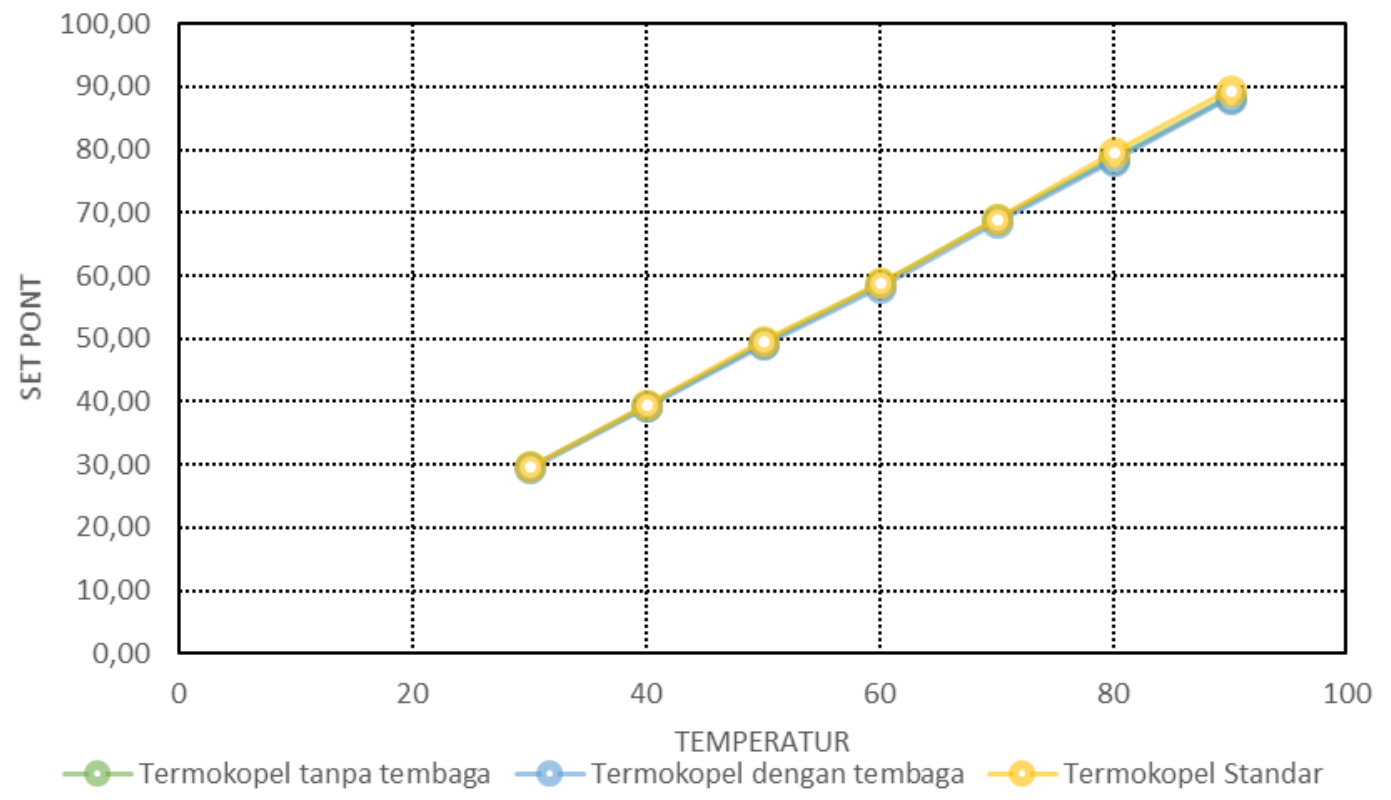

Gambar 14. Grafik karakterisasi termokopel tipe K pada FASSIP-02

Grafik pengujian pada termokopel tanpa terbungkus tembaga pada juction menghasilkan pengukuran yang lebih besar daripada termokopel yang terbungkus dengan tembaga pada junction karena transfer panas dari air ke termokopel terjadi secara langsung pada ujung kawat termokopel tanpa melalui konduktor tembaga sehingga respon pengukuran pada termokopel lebih cepat. Ratarata perbedaan temperatur termokopel terbungkus tembaga dan tidak terbungkus tembaga pada 
junction sebesar $0,37^{\circ} \mathrm{C}$. Perbedaan termokopel terbungkus tembaga pada junction dengan termokopel standar sebesar $0,75^{\circ} \mathrm{C}$. Dari data hasil pengujian dapat diperoleh rata-rata kesalahan dengan rumus kesalahan harga sebenarnya dalam proses dari termokopel standar sebesar 1\%, termokopel terbungkus tembaga $2,17 \%$ dan tanpa terbungkus tembaga $1,45 \%$. Perbedaan pengukuran termokopel terbungkus tembaga pada junction dengan termokopel standar dan termokopel tidak terbungkus tembaga pada junction menghasilkan perbedaan yang kecil. Rata-rata kesalahan pada termokopel dengan terbungkus tembaga pada juction juga diperoleh nilai yang kecil maka pengukuran termokopel tipe $\mathrm{K}$ terbungkus tembaga pada junction untuk FASSIP-02 dapat dilakukan pengukuran.

\section{SIMPULAN}

Dari hasil pengujian karakterisasi termokopel tipe K pada FASSIP-02 didapatkan hasil ratarata kesalahan pada termokopel standar sebesar 1,01\%, termokopel terbungkus tembaga pada ujung juction 2,17\% dan termokopel tanpa terbungkus tembaga sebesar 1,45\%. Dari hasil tersebut dapat disimpulkan pada pengujian termokopel yang ujung juction terbungkus tembaga menghasilkan pengukuran kesalahan yang lebih besar daripada termokopel yang ujung junction tanpa terbungkus tembaga karena transfer panas dari air ke termokopel yang terbungkus tembaga pada ujung junction termokopel terjadi secara tidak langsung dan melalui konduktor tembaga sehingga menghasilkan respon pengukuran yang lebih lama daripada termokopel yang ujung juction tidak terbungkus tembaga. Dari hasil rata-rata perbedaan termokopel yang ujung juction terbungus tembaga dengan yang tanpa terbungkus tembaga menghasilkan nilai yang kecil yaitu $0.37^{\circ} \mathrm{C}$. Untuk hasil rata-rata perbedaan termokopel yang ujung junction terbungkus dengan tembaga dengan termokopel standar menghasilkan nilai yang kecil yaitu $0.75^{\circ} \mathrm{C}$. Dari nilai tersebut maka penggunaan tembaga sebagai sebagai pembungkus ujung juction termokopel dapat digunakan sebagai pengukuran temperatur pada FASSIP-02.

\section{UCAPAN TERIMA KASIH}

Kami ucapkan terima kasih atas dukungan yang diberikan oleh; Program Insinas Riset Pratama Kemenristekdikti tahun anggaran 2018, Badan Tenaga Nuklir Nasional (BATAN) dan PTKRN BATAN yang telah menyediakan tempat penelitian dan Kepala BPFKR selaku atasan langsung dan teman-teman Subbidang Fasilitas Termohidrolika atas diskusi teknis.

\section{DAFTAR PUSTAKA}

[1] Lumbanraja, Sahala Maruli, Riyanti, Rr Arum Puni, \& Anggoro, Yohanes Dwi. (2011). Manajemen Keselamatan PLTN Pasca Kecelakaan Fukushima Daiichi Unit 1 4. Jurnal Pengembangan Energi Nuklir, 13(2).

[2] Baba, M. (2013). Fukushima accident: What happened? Radiation Measurements, 55, 17-21.

[3] Zhang, YP, Qiu, SZ, Su, GH, \& Tian, WX. (2012). Design and Transient Analyses of Emergency Passive Residual heat Removal System of CPR1000. Nuclear Engineering and Design, 242, 247-256.

[4] Sumantri Hatmoko, Djiwo Harsono, Sudarno. (2016). Rancang Bangun Sistem Monitoring dan Pengukuran Parameter Thermohidrolika Berbasis Labview pada Untai FASSIP. Seminar SDM Teknologi Nuklir STTN Yogyakarta.

[5] Suntoro, Achmad. (2017). Karakteristik Termokopel Tungsten-Rhenium (W-3\% Re/W-25\% Re). PRIMA-Aplikasi dan Rekayasa dalam Bidang Iptek Nuklir, 1(1), 15-18.

[6] Ramada, Putra Dwi, \& Sudiartono, MS. (2017). Karakteristik Perbandingan Termokopel Tipe K, Termokopel Tipe E, Termokopel Tipe K, dan Termokopel Tipe $N$ untuk Suhu 0'C Sampai Suhu $100^{\circ} \mathrm{C}$. Universitas Gadjah Mada. 
[7] Juarsa, Mulya. (2015). Laporan Penelitian Studi Eksperimental Fenomena Sirkulasi Alamiah Aliran Satu-Fasa untuk Pengembangan PRHRS Menggunakan Untai FASSIP-01. PTKRN BATAN. Serpong.

[8] Muhammad, Irvan S. (2009). Teknik Kalibrasi Termokopel Tipe K di PT. Inalu Muara Kujang. (Teknologi Instrumentasi Pabrik), Universitas Sumatra Utara, Medan.

[9] Rachman, Agus Nur, \& Wahanani, Nursinta Adi. (2017). Pengembangan Sistem Instrumentasi Thermobath dan Akuisisi Data Termokopel Tipe K. SIGMA EPSILON-Buletin Ilmiah Teknologi Keselamatan Reaktor Nuklir, 20(1).

[10] Ginting, Suriadi. Penggunaan Sensor Pyrometer sebagai Alat untuk Mengukur Temperatur Material pada Kiln (Aplikasi PT. Semen Padang).

[11] https://www.omega.co.uk/pptst/TL_WELD.html), diakses pada April 2018.

[12] http://sine.ni.com/psp/app/doc/p/id/psp-914/lang/en), diakses pada April 2018.

[13] http://www.ni.com/en-id/support/model.ni-9213.html), diakses pada April 2018.

[14] http://elektro2017.blogspot.co.id/2012/11/an-introduction-tutorial-of-labview.html), diakses pada April 2018.

[15] http://www.techne.com/product.asp?dsl=198), diakses pada April 2018. 